\title{
Managing workplace religious expression within the legal constraints
}

\author{
Andrew Hambler
}

University of Wolverhampton Business School, University of Wolverhampton, Wolverhampton, UK ${ }^{1}$

\begin{abstract}
Purpose - The purpose of this paper is to consider in broad terms how employers may respond to different forms of religious expression by employees in the workplace, within the discretion afforded to them by law.
\end{abstract}

Design/methodology/approach - Through a discussion of relevant legislation and case law, and a review of relevant literature, it seeks to identify the legal constraints within which employers must operate when determining policy and practice in this area and gives consideration to how they should respond.

Findings - It is observed that employers enjoy considerable freedom either to impose restrictions or to encourage religious expression.

Originality/value - The paper considers some of the over-arching principled arguments both for and against encouraging religious freedom at work, whilst concluding that support for religious expression may be the better option, not least for the positive benefits for employee well-being, commitment and engagement which, it is argued, may result.

\section{Introduction}

On Monday 14 July 2014, a Muslim cashier employed by Tesco (in Neasden, London) reportedly declined to serve a customer who was trying to buy wine and meat because he said it was Ramadan, and he suggested she go to the self-service till instead. She complained and the store manager had to decide how to address the issue in a 'pragmatic' way without the aid of any clear policy guidelines. He also told the customer to use self-service. This story made it to the pages of the Daily Mail (16 July 2014), including a sympathetic interview with the irate customer, and so generated negative publicity for the supermarket chain.

\footnotetext{
${ }^{1}$ This paper is based, in part, on a short paper submitted to a competition organised by the Chartered Management Institute (CMI) in 2014 and subsequently published in CMI, Winning Ideas: the Management Articles of the Year (February 2015), pp. 14-19. Material from that paper is reproduced here with the kind agreement of the CMI.
} 
This particular (and rather minor) incident is one of many everyday examples of what can be a potentially vexing issue for managers and indeed for organisational policy-makers - how to deal with religious expression by employees in the workplace? Recent survey findings, published by the Equalities and Human Rights Commission, provide evidence that the problem is a real one for many employers, a general finding being the need for a greater 'understanding of when, and in what ways, requests relating to an individual's religion or belief should be accepted' (Mitchell et al., 2015, p. 11). Employees may wish to express their beliefs in a number of ways (Hicks, 2003) and these can have differential effects on the organisation. There are numerous examples of forms of religious expression, but the majority (and certainly those forms which have led to legal disputes at work) can be categorised under the following broad groupings:

a) Dress/Personal Appearance. Many religious adherents choose (or feel obliged) to express their religious beliefs through dress and grooming or the wearing of religious symbols (Howard, 2012). Sikh women, for example, may wear the Kara bracelet and some Sikh, Jewish and Muslim men may choose to wear facial hair.

b) Working Time. Some religious employees feel a particular desire not to be at work at particular times or on particular days due to what they may regard as the higher obligations imposed by their religious beliefs. For example, many Christians may object to working on Sundays and observant Jews on Saturdays (Gavison and Perez, 2008); equally some Muslims feel under an obligation to engage in congregational prayer (the Jumu'ah) on Friday lunchtimes (Muslim Council of Britain, 2005). Where employees do not have time to leave the premises they may make requests for accommodations to allow for religious devotions within the workplace (e.g. the allocation of a dedicated prayer room facility).

c) Conscientious Objection. Some employees (or public officials) with religious convictions may experience difficulties with performing an aspect of a normal job role due to conflicts with religiousbased conscience (Litwak, 2005), such as Christian registrars who may object to performing samesex marriages or Civil Partnerships (Parkinson, 2011), or indeed Muslim supermarket employees who feel it is wrong for them to handle alcohol.

d) Religious Speech. Some employees may wish, or feel compelled, to 'verbalise' their religious convictions in the workplace, for example by offering to pray for customers, or by attempting to make religious converts from amongst co-workers (Berg, 1998-99).

The purpose of this article is to explore the approaches available to managers and organisations in dealing with such issues, in the context of a liberal Western democracy (with a mature framework of 
anti-discrimination and human rights law). The democracy in question is the United Kingdom and the article has a particular focus on the legal jurisdiction of England and Wales. Although the legal position, particularly in some of the detailed development though case law, is specific to that jurisdiction, there are some clear parallels with comparable Western democracies, not least the other EU states, all of which share membership of the European Convention on Human Rights and Fundamental Freedoms (a requirement of EU membership) and are also bound by the Equal Treatment Framework Directive, which outlawed discrimination on the grounds of religion and belief across the EU (Council Directive 2000/78/EC). It is therefore suggested that this article, focussed on the UK, provides an example of how to approach religious expression at an organisational level, which has wider implications for organisations in liberal democracies elsewhere, albeit that cultural and institutional differences mean that parallels will be inexact.

The article seeks to identify: the legal constraints on managers' freedom of action; the extent to which they enjoy a measure of discretion in their treatment of individual religious expression; issues they may wish to consider before using that discretion; and any HR or organisational policy considerations arising. The article concludes by encouraging managers to maximise their toleration of religious expression at work, albeit recognising that there must be limitations to that freedom.

\section{The Legal Constraints}

In some legal jurisdictions, for example in Canada and in the United States, there is a positive duty on the employer to 'reasonably accommodate' religious practices in the workplace (Fredman, 2011). There is no such duty in the UK, although it has been argued by some that this might be beneficial (Hepple et al, 2000; Gibson, 2013). Instead, religion (alongside belief) is a 'protected characteristic' under discrimination law (Equality Act ('EA') 2010, s 10), which means that employers cannot treat people 'less favourably' than others because of their religion - this would constitute direct discrimination (EA 2010, s 13). It also means that they cannot subject employees (or prospective employees) to 'indirect discrimination' (EA, s 19), i.e. they cannot apply a staffing rule ('a provision, criterion or practice') which appears neutral but which in fact has an adverse impact on some staff because of their protected characteristic (unless this can be justified as 'a proportionate means of achieving a legitimate aim'). For example, an employer cannot arbitrarily impose a rule in a dress code that all staff should have their heads uncovered. Such a rule would impose no real burdens on the majority of staff but it would impose a substantial burden on some Sikh men and some Muslim women. Such a rule would require a strong justification related to the requirements of the job, otherwise it would constitute unlawful indirect religious discrimination. 
The law is still more complex because there are some specific exemptions for particular religious practices, e.g. to allow the wearing of the turban instead of an otherwise mandatory hard hat by Sikh construction workers (Employment Act 1989, s 11). There is also an absolute legal right under Article 9 of the European Convention on Human Rights, written into domestic law in the form of the Human Rights Act 1998 (Leigh and Masterman, 2008), to 'freedom of thought, conscience and religion'; allied to this, there is a qualified right to 'manifest' (which essentially means the same as 'express') these beliefs in 'worship, teaching, practice or observance', unless a national government has good reason to impose constraints ('in the interests of public safety, for the protection of public order, health or morals, or for the protection of the rights and freedoms of others'). Although it was once thought that Article 9 did not apply in certain 'specific situations' such as employment (Kalac $v$ Turkey; Hill et al., 2011), as a result of a seminal judgment by the European Court of Human Rights in January 2013 (Eweida and Ors v United Kingdom), it is now clear that Article 9 applies in the workplace as elsewhere (although the implications of this have yet to be clearly articulated in domestic case law).

Although employees who have complained before the courts of religious discrimination by their employers have invoked inter alia direct discrimination in support of their claims, it is clear that indirect discrimination offers the most promising avenue for redress, as it puts employers under an obligation to justify their apparently neutral work practices which nevertheless have a discriminatory impact on specific groups of employees on the grounds of their religious beliefs. Direct discrimination is generally quite straightforward for employers to successfully respond to, as they are able to argue that they treat, or would treat, all employees in the same way; as a result there can be no direct discrimination. Thus, if a Muslim employee were to be disciplined for wearing a headscarf in contravention of a uniform rule, the employer could argue that it would have disciplined any employee who chose to wear a headscarf, regardless of religious affiliation, so there can be no direct discrimination. However, such a uniform rule would be prima facie indirectly discriminatory against Muslim women as it imposes a provision, criterion or practice which Muslims would find much more onerous to comply with than would non-Muslim staff. The burden would then fall on the employer to justify its position. Thus, given the significance of the issue, it is to the potential employer justifications for indirect discrimination, in the various domains of religious expression set out earlier, to which this discussion will now turn.

\subsection{Dress/Personal Appearance}

In developing a policy for regulating religious dress and personal appearance in the workplace, employers are likely to find justifications for imposing restrictions, either because of the nature of 
the job itself, or in order to display a consistent image to the public, or in response to health and safety concerns. Some employers have developed policies which take into account whether or not the religious practice in question is mandatory to the religion concerned. If so, it is more likely to be accepted as a potential exception to an otherwise generally applied uniform rule. Case law has demonstrated that organisations are most likely to be able to justify restrictions where there is significant interference with operational requirements or where there are health and safety concerns.

For example, in the case of Azmi $v$ Kirklees Borough Council, a language support assistant unsuccessfully claimed she had suffered discrimination when her employer refused permission to wear a burqa. It took advice and conducted extensive research to support the contention that the nature of her job demanded that the children should be able to see her mouth and facial movements. The Employment Appeals Tribunal found that the employer had met the test of justification. As another example, in Chaplin v Royal Devon and Exeter Hospital NHS Foundation Trust, a nurse was refused permission to wear a visible cross as a necklace for fear that it might cause injury to others. The tribunal found that health and safety concerns provided an adequate justification for the restriction, a decision later endorsed by the European Court of Human Rights (Eweida and Ors $v U K$ ), in spite of the fact that little actual evidence was produced by the employer to demonstrate a health and safety issue.

However, it is clear from the ruling in Eweida and Ors that dress codes excluding religious symbols will not always meet the justification test. Eweida was a British Airways employee refused permission to wear visible jewellery, including a small cross which had religious significance for her. The rationale for the policy was to display a consistent image to the public. The European Court found that the employer's justification (corporate image) was not 'weighty' enough when compared to Eweida's sense of religious obligation. This is important as many dress codes are concerned primarily with image rather than health and safety or operational needs. This ruling (which must be incorporated into the way courts apply domestic law) suggests that managers would be wise to be flexible in such circumstances.

The other important point for employers arising from Eweida and Ors is that it is no longer acceptable for an employer to make its own determination of what kind of religious practices might be considered necessary to a particular religious belief and make exceptions to dress codes for those only (Hill, 2013; Leigh and Hambler, 2014). For example, British Airways had originally made some exceptions for Muslim and Sikh dress, because these were 'mandatory' to Islam and Sikhism, but not for the Christian cross as this was not considered mandatory to Christianity. The court was quite 
clear that what matters is the individual's sincere belief that they ought to wear a particular symbol and neither courts nor employers should make judgments beyond this.

\subsection{Working Time}

Organisations are not obliged to action requests for time off for religious activities away from the workplace if these interfere with operational need, which might include difficulties in reassigning duties to other staff. This was confirmed in Mba v Merton Borough Council, a case involving a Christian care home worker who took a literal view of the Fourth Commandment (Exodus 20: 8-11), which mandates rest on the Sabbath, and so believed it was wrong in principle to work on Sundays. For two years her employer accommodated her, and she did not work on a Sunday, but then decided that this arrangement was too costly and disruptive for staff scheduling (and required the use of bank staff for cover) and for continuity of care for children. It therefore required Mba to work occasional Sundays on a rotation basis. She refused to so and as a result she was given a final written warning. This led to her resignation and a tribunal claim, inter alia, for indirect religious discrimination. The Court of Appeal found that the employer's operational requirements and financial constraints together amounted to a sufficient justification for its otherwise indirectly discriminatory conduct towards Mba, and dismissed her claim.

\subsection{Conscientious Objection}

Except where there are specific provisions in statute or professional regulations for conscientious objection (chiefly in medicine or pharmacy), there is limited protection for religious-based conscience in law, in particular where it may affect the rights of others. This was made clear in Ladele $v$ Islington Borough Council where a Christian Registrar of Marriages was refused permission to 'opt out' of conducting same-sex Civil Partnership ceremonies (on the basis that she felt it was wrong for her to 'promote' something she regarded as 'sinful'). The Court of Appeal determined that although the Council could have accommodated Ladele on a practical level with minimal service disruption, nevertheless it was justified in refusing to do so because of its inclusive 'Dignity for All' policy and its belief that all staff should demonstrate commitment to it. This decision was unsuccessfully challenged at the European Court of Human Rights (Eweida and Ors $v$ UK). Some commentators have been critical of the decisions in this case on the basis that the courts should have required a higher (and more concrete) standard of justification from the employer than they did (e.g. Parkinson, 2011; Leigh and Hambler, 2014). However, it is significant that the Courts made it clear that Islington Borough Council could have accommodated Ladele had it so wished and two 
judges in the European Court, in a minority opinion, argued that it should have done (Judges Vucinic and De Gaetano).

\section{$2.4 \quad$ Religious Speech}

The legal position on religious speech has not been clearly tested before courts and tribunals so there is limited guidance for managers. What is clear is that organisations should be very careful not to penalise the voicing of unfashionable religious opinions outside of a work context. This was confirmed in Smith $v$ Trafford Housing Trust, in which a claim was brought by a Christian Housing Manager who had been demoted with a $40 \%$ pay cut after posting comments on his Facebook site apparently critical of the possibility that same-sex marriages might take place in churches. The Trust claimed that such posts amounted to gross misconduct because they might have damaged its reputation (Smith had named the Trust as his employer on his personal profile) and did involve a breach of the code of conduct for staff (by promoting religious views to co-workers and clients). The judge rejected the employer's arguments, finding that there was no realistic damage to the Trust's reputation, given that the postings were made by an employee outside of working hours, in a private capacity, and conveyed in a moderate way. He also noted that an employer had no general right to interfere with an employee's right of freedom of religious expression in respect of non-work activities (albeit that there may be occasions when the distinction between working and nonworking is blurred (Mantouvalou, 2008)).

Where employees do verbalise their religious beliefs, employers have sometimes disciplined them for harassing co-workers or clients and this has been accepted by the courts. For example, in Chondol v Liverpool City Council, a Christian social worker was dismissed after giving a Bible to one (potentially 'fragile') 'service-user' and of sharing his religious views with another, both of which were considered improper. The Employment Appeals Tribunal found the dismissal to be fair, given the specific context and the employment role. In the NHS there now appears to be a fairly consistent position that clinical staff can discuss their religious beliefs with patients (or make an offer to pray) but only if the patient initiates the conversation (e.g. GMC, 2013). Some general guidance written to help employers form policy in this area (e.g. that produced by the British Humanist Association) is misleading because it appears to imply that religious speech of itself creates an 'intimidating, hostile, degrading, humiliating or offensive environment' (the second limb of the definition of harassment under EA 26(2)(b)(ii)). Although discrimination case law is under-developed in this area so firm conclusions cannot be reached, it does seem that harassment is only likely to occur if the religious speech reaches a certain threshold whereby it can be described as 'improper' (as in Kokkinakis $v$ Greece under Article 9 ECHR). This in turn will depend not only on the nature of the speech itself but 
also the context in which it is made and the relevant characteristics of the parties involved, such as the power relationship between them (Stahnke, 1999). Mild and respectful religious speech will be difficult to describe as 'improper' and therefore very unlikely trigger a successful harassment claim. Thus, organisations may be acting unreasonably if they refuse to allow any voicing of religious beliefs in the workplace (Berg, 1998-99).

\section{Exercising Managerial Discretion}

Thus far some examples of religious expression at work have been presented under a loose categorisation. How employers are constrained by the law, in particular the Equality Act and the way it has been understood by tribunals and courts, has been considered. What is apparent is that organisations and their managers retain a good deal of discretion in how to deal with incidence of religious expression. Indeed it has been argued that courts allow employers more flexibility when seeking to justify their dealings with religion and belief at work than with other protected characteristics, such as race and sex (Vickers, 2010). However, regardless of this wide latitude and even where there is a strong justification before the law for constraining religious expression for various reasons, managers can often still choose to be accommodating should they be persuaded that this is the right approach. The discussion will therefore move towards a consideration of the principles at stake - the rationales both for and against permitting (or even encouraging) religious expression in the workplace.

Famously Alastair Campbell, press officer to former Prime Minister Tony Blair, prevented any discussion of Blair's religious beliefs in a media interview by the stark assertion 'We don't do God' (Daily Telegraph, 4 May 2003). In the process, he delineated a distinction between having religious beliefs in private and manifesting them in public. This notion that religion is something private has seeped into the public consciousness, such that articulating religious convictions publically is sometimes looked on as out of place, even vaguely disreputable. There is some theoretical support for such a view. The political philosopher John Rawls $(1977 ; 1993)$ identified occasions where there is what he described as a 'duty of civility' for citizens to divorce themselves from their religious convictions when making decisions which might impact on others. Other writers have critically considered the possible implications of the same reasoning for the workplace context (e.g. Pava 1998; Fort, 1998).

The basic assumption underlying this view is that religion polarises opinion in an unhelpful way; there is discord and disruption when one individual seeks to 'impose' his or her religion (which others do not share) on other people in the workplace (as elsewhere). The potential for this is most 
obvious perhaps when employees seek to verbally express their religious beliefs and possibly offend their co-workers or customers (Berg, 1998-99); but it can also apply, for example, to the wearing of (certain) religious symbols, on the basis that this might pressurise younger people into religious conformity (Bennoune, 2007), and even to granting employees time off for religious obligations where covering for this places a burden on the rest of the workforce (Jones, 2014). To avert such conflict, so the reasoning goes, the workplace should be kept secular; employees should leave their beliefs at the threshold of the workplace, because they have no place inside. Cintas et al (2013) appear to be sympathetic to this view, in their analysis of the management of religious diversity in French organisations. Although the authors do concede that there may be some (unproven) organisational benefits to be gained by taking account of religious identities in the practice of human resource management, they seem to suggest that such benefits are outweighed by the negative effects, which they summarise as follows (p. 588):

Recognition of religious identity ... leads to tolerance of practices which disrupt relational codes and civility (refusal to shake hands or take communal meals) as well as work organisation (additional constraints on the regulation of absence). All rules that apply only to one section of the workforce create inequalities between employees and undermine group cohesion and, in the long term, have an adverse effect on economic efficiency.

On this basis, they tentatively argue that the workplace should be managed according to the principles of secularism. Those organisations which find such a view persuasive will allow it to inform both policy making and managerial decision-making within the area of permitted employer discretion. Religious expression will thus be discouraged as much as possible, within the legal constraints.

The rationale underlying this view is of course highly controversial. Many religious people object to the idea that they can 'privatise' their beliefs and keep them out of a public forum such as the workplace. As Ahdar and Leigh (2013, p. 157) observe:

The most mundane of human behaviours can be 'spiritualised' and take on a religious connotation. One is practising one's religion when one eats, drinks, works, plays and gardens, as much as when one reads scripture, prays or meditates ... .

For people who approach their faith in this way, religious beliefs infuse everyday living and working and so cannot be removed like a coat at the door of the office. Some religious employees may also consider themselves to be under a positive duty to express their religion in different ways which affect the workplace (Hambler, 2015; Kaminer, 2000). Where the employer is unwilling to allow this, 
it will either force staff to act against conscience, or it will exclude them entirely. Requiring staff to act against conscience can create significant costs for them, resulting at worst, as Childress (1979, p. 318) notes, 'not only in such unpleasant feelings as guilt and/or shame but also in a fundamental loss of integrity, wholeness, and harmony in the self.' Either employees will seek somehow to accommodate these feelings, with the consequent ill effects for morale, individual well-being and productivity, or they will leave. One consequence of the latter will be to undermine 'diversity' (given that some religious employees may be de facto excluded from the workplace), a value which is often held in high regard by managers, partly because of the business benefits it is said to bring (Kandola and Fullerton, 1998; Kirton and Greene, 2010). Such an exclusionary approach can also create industrial relations and even reputational problems. The employment tribunal statistics illustrate that employees are often quite prepared to launch claims (regardless of the legal merits) if they feel they have suffered religious discrimination, bringing all the costs and distracting activities which such cases entail for organisations. There may also be adverse media coverage, as there are influential religious interest groups such as the Christian Legal Centre which employ skilled press officers, good at bringing attention to religious claims where it appears employers are acting unfairly (Christian Legal Centre, 2012).

There is also a positive case for welcoming religious expression as a general principle which is based in part on two values thought to be fundamental to liberal Western democracies - autonomy and dignity. Autonomy represents the right of individuals to make fundamental choices in pursuit of their own version of the good life (Ahdar and Leigh, 2013). Such fundamental choices should be respected and not impeded by society or indeed by employers so that an individual can fully flourish. When individuals flourish at work this is likely to be associated with higher levels of employee engagement and productivity and lower levels of stress, absenteeism and staff turnover. An individual's personal autonomy will be maximised the more he or she can fully express his or her deepest convictions, including of course religious ones. Dignity is a more difficult concept to quantify (McCrudden, 2008), beyond the fact that it refers to the essential worth of people because of their humanity and that this is deserving of respect by others. Dignity can be defined in more specific ways: Feldman (1999, p. 686), for example, develops the notion of dignity at an individual level arguing that it requires that people 'be treated in particular ways which advance or do not unduly interfere with the acquisition or maintenance of ... physical or moral integrity'. This conception of dignity is helpful in understanding the fundamental importance to individuals of making moral choices (which in turn are likely, in many cases, to be guided by and bound up with religious belief) and why these choices should be respected by other actors, including employers, to the extent that it is possible to do so. 
Of course there will be occasions where particular forms of religious expression impose unacceptable costs on the employer or co-workers, perhaps where genuine health and safety concerns or genuine operational constraints exist or actual harassment ('improper' religious speech) of other staff is occurring. On such occasions, arguably employers should take care to confirm that the apparent reasons for restrictions are genuine and not contrived (this may be particularly relevant where 'health and safety' is invoked sometimes for spurious reasons (Hambler, 2015)). Equally, where an employee has apparently 'harassed' a co-worker through his or her religious speech, employers may wish to exercise moderation in their response (certainly for a first offence). As some practical advice to employers puts it (Hunt, 2009, p. 33):

Even if a member of staff seems to be acting in a discriminatory way, treat them with dignity and respect. Find ways to solve the problem, rather than excluding or discriminating against the individual. ... Bring in other parties in to help if two parties are struggling to find common ground. Mediation and training is often more effective in the long term than disciplinary action.

Some employers, however, appear to have over-reacted in such cases by summarily dismissing an employee where a lesser disciplinary sanction might have sufficed (e.g. Amachree $v$ Wandsworth Borough Council; Chondol v Liverpool City Council), thus unnecessarily losing potentially a good employee and inviting legal action.

It is also arguable that religious employees, particularly those sufficiently committed to their beliefs that they want to manifest them overtly at work, are, or ought to be, amongst the most committed and 'virtuous' employees, as they are working not simply for their managers but also for God (Ahdar and Leigh, 2013; Tayeb, 1997). In so doing they are demonstrating what Audi (2000, p. 118) calls 'secularly-aligned religious obligations' and are likely to have a clearly articulated ethical framework for their behaviour at work (Fort, 1998). Such employees are the kind most organisations would want and so, it may be argued, they should be fully embraced. Although it should be noted that the extent to which stated religious belief actually affects individual behaviour at work may be exaggerated (Wuthnow, 1998), dependent inter alia on the strength of religious commitment at an individual level (Leader, 2007), there is some (limited) empirical evidence to support a positive link between religious convictions and performance at work (Osman-Gani et al., 2013). Those employers 
who find this evidence persuasive may decide to maximise the opportunities for religious expression, perhaps even to the point of accepting a degree of additional cost.

\section{Implications for Organisational Policy}

Given the potential complexity of the issue of freedom of religious expression at work, it is likely that many organisations may wish to develop clear HR policies to provide a framework for managers in responding to examples of employee religious expression. For those organisations which particularly see the value of it, for motivating and retaining good staff and for fostering and encouraging workplace diversity, then such policies will aim to maximise opportunities for religious expression. How this might look will depend on the particular domain of religious expression:

a) Dress/Personal Appearance. Arguably, since the decision in Eweida and Ors, only genuine operational considerations, hygiene or health and safety can provide acceptable justifications for restricting the wearing of religious dress or symbols and personal grooming. It is likely that most organisations can make significant changes without major difficulty to dress codes to create religious exemptions. Indeed there is published evidence that a number of organisations, in sometimes surprising industries, are able to adapt uniforms to incorporate the ability to wear one of the most prominent examples of religious dress - a Muslim headscarf - without significantly compromising corporate identity (Lewis, 2013).

b) Working Time. Given that managers will have little choice but to deal with applications for alterations to working patterns to accommodate religious practices very probably through the mechanism of a statutory request to work flexibly under the Employment Rights Act 1996, s 80F (as amended by the Children and Families Act 2014, s 131(1)), then formulating an organisational approach to dealing with such requests is likely be required. One way would be to approach such requests in exactly the same way as any other requests for flexible working. However, it is arguable that requests with a religious motivation for specific days should be given a degree of priority. For example, if an employer is faced with two sets of requests to avoid Sunday working, one from a Christian employee who wishes to attend Church; another from a working parent who wants to spend time with family, then it would be legitimate to prioritise the request from the Christian employee because it is associated with the 'protected characteristic' of religion. Indeed, although this has not yet been tested in law, it may be indirectly discriminatory not to so prioritise. It might be helpful to identify this issue in any policy guidelines produced for managers. What may be more 
common are requests for accommodations which are brought only by religious employees and which employers wish to turn down on grounds of operational efficiency or cost (the situation in Mba v Merton $B C$ ). Whereas the law appears to consider that these grounds constitute examples of a legitimate aim for the employer, there may be circumstances in which employers take a decision to accept a degree of additional cost or inconvenience for the quid pro quo of enhanced employee loyalty and commitment and/or as a retention strategy to keep a good employee. A decision on a matter such as this may be made on a case-by-case basis, but with consistent criteria applied when determining whether or a not a potentially costly request is to be accommodated. As with all forms of accommodation (such as the legal duty to make reasonable adjustments for employees with a disability), larger employers are likely to find this easier than small or medium-sized employers.

c) Conscientious Objection. Dealing with requests from employees with an objection to some aspects of their work is arguably quite straightforward and can be enshrined in policy or left to managerial discretion. The question to be applied should be, if this objection is accommodated, will it make a material difference to any services the organisation provides to others? Put another way, can this request be easily accommodated on a practical level with minimal inconvenience to other actors? If the answer to this second question is yes, then it may be argued that the objection should be accommodated (Wilson, 2010). If the answer is no, then considerations similar to those mooted at (b) above (relating to staff engagement and retention) are likely to determine whether or not the accommodation will be made anyway. If the rights of others are affected however, in a way which is more than minor (e.g. members of the public are actually denied a service, such as a civil partnership, to which they have a legal right), then it would be very difficult to justify an accommodation.

d) Religious Speech. This is potentially the most difficult area for employers to navigate as religious speech can potentially manifest itself in many ways and, in extreme cases only, could lead to the harassment of other employees. It may be argued that employers should seek to create an open climate where beliefs and opinions of various kinds can be shared respectfully. There may be a role for the organisation development function to seek to foster this. If employees do harass others through aggressive proselytism or abuse of position, then this is likely to be a disciplinary offence. However, what constitutes aggressive (or inappropriate) proselytism should be carefully defined by the employer to avoid encompassing legitimate religious discussions, including an element of respectfully 'bearing witness' to others (Kokkinakis $v$ Greece). Arguably more academic and policy research is required to assist employers in making such distinctions, although there has been some limited research in similar areas aimed at legal policy makers (e.g. Stahnke, 1999). Equally, 
employers should not be in a rush to categorise inappropriate religious speech as 'gross misconduct' and potentially a first instance dismissible offence - it is likely to be more suitably categorised as 'misconduct' which at least allows an opportunity to learn from perhaps a well-intentioned error of judgment or misplaced zeal. If the religious speech involves criticism of others (e.g. because of their sexual orientation) then the context of the apparent criticism needs to be considered (what was said, how was it said and who initiated the conversation?). If the religious speaker is at serious fault, to the point of being guilty of harassment, then again (unless the harassment has been so serious as to leave no realistic alternative to summary dismissal) it may be argued that this should be considered 'misconduct' rather than gross misconduct for a first offence.

\section{Conclusion}

Religious expression is controversial and the extent to which it should be tolerated in the workplace in a liberal democracy such as the United Kingdom is contested. There is a legal framework which circumscribes employer action and provides a measure of protection (albeit quite a limited one), chiefly through the legal mechanism of indirect discrimination. Employers also have an obligation to other staff and at some point religious expression, if entirely unfettered, may infringe the real rights of other employees. However, between these two constraints, there is a large measure of discretion for organisations and their managers.

Whilst a rationale for seeking to minimise religious expression has been considered in this article, so too has a rationale for seeking to maximise opportunities for religious expression (alongside some practical implications for organisational policy-making). It may be argued that this latter rationale is in general more persuasive for the benefits it entails for individual dignity and well-being, with potential positive consequences for organisations. Organisations will decide how far they wish to align themselves with these respective minimal or maximal approaches to religious expression at work. They should however do so in an informed way and, to reduce potential employment relations problems, they should operationalise their approach through a detailed examination of its implications for HR policies and managerial practices. Unfortunately they will need to do this without the benefit of a particularly full body of academic or policy material on the subject - a knowledge gap which HR and policy researchers could usefully set about starting to fill.

\section{References}

Ahdar, R. and Leigh, I. (2013), Religious Freedom in the Liberal State, 2nd edn., Oxford, Oxford University Press. 
Audi, R. (2000), Religious Commitment and Secular Reason, Cambridge, Cambridge University Press.

Bennoune, K. (2007), "Secularism and Human Rights: A Contextual Analysis of Headscarves, Religious Expression and Women's Equality under International Law", Columbia Journal of Transnational Law, Vol. 45 No. 2, pp. 367-426.

Berg, T. (1998-1999), "Religious speech in the workplace: harassment or protected speech?", Harvard Journal of Law and Public Policy, Vol. 22, pp. 959-1057.

British Humanist Association, Guidance on Equality of 'Religion or Belief', available at: http://www.humanism.org.uk/ uploads/documents/GuidanceFinal2.pdf (accessed 25 March 2015).

Brown, C. (2003), “We don't do God", Daily Telegraph, London, 4 May 2003.

Childress, J. (1979), “Appeals to Conscience”, Ethics, Vol. 89 No. 4, pp. 315-335.

Christian Legal Centre (2012), Case Summaries, available at: http://www.christianconcern.com/sites/default/files/docs/ChristianLegalCentre-CaseSummaries.pdf (accessed 25 March 2015).

Cintas, C., Gosse, B. and Vatteville, E. (2013), "Religious identity: a new dimension of HRM? A French View”, Employee Relations, Vol. 35 No. 6, pp. 567-592.

Feldman, D. (1999), "Human dignity as a legal value: Part 1", Public Law, Winter, pp. 682-702.

Fagge, N. (2014), "Tesco apologises after Muslim checkout worker refused to sell customer ham and wine because it was Ramadan", Daily Mail, 16 July 2014.

Fort, T. (1998), "Religion in the Workplace: Mediating Religion's Good, Bad and Ugly Naturally", Notre Dame Journal of Law, Ethics \& Public Policy, Vol. 12 No. 1, pp. 121-171.

Fredman, S. (2011), Discrimination Law, 2nd edn., Oxford, Oxford University Press.

Gavison, R. and Perez, N. (2008), "Days of rest in multicultural societies: private, public separate", P. Cane, C. Evans and Z. Robinson (Eds.), Law and Religion in Theoretical and Historical Context, Cambridge, Cambridge University Press, pp. 186-213.

General Medical Council (2013), Personal Beliefs and Medical Practice, London, March 2013.

Gibson, M. (2013), “The God 'Dilution'? Religion, Discrimination and the Case for Reasonable Accommodation", Cambridge Law Journal, Vol. 72 No. 3, pp. 578-616.

Hambler, A. (2015), Religious Expression in the Workplace and the Contested Role of Law, Abingdon, Routledge.

Hepple, B., Coussey, M. and Choudhury, T. (2000), Equality: A New Framework. Report of the Independent Review of the Enforcement of UK Anti-Discrimination Legislation, Oxford, Hart.

Hicks, D. (2003), Religion and the Workplace: Pluralism, spirituality, leadership, Cambridge, Cambridge University Press. 
Hill, M. (2013), "Religious Symbolism and Conscientious Objection in the Workplace: An Evaluation of Strasbourg's Judgment in Eweida and others v United Kingdom", Ecclesiastical Law Journal, Vol. 15 No. 2, pp. 191-203.

Hill, M., Sandberg, R. and Doe, N. (2011), Religion and Law in the United Kingdom, The Hague, Wolters-Kluwer.

Howard, E. (2012), Law and the Wearing of Religious Symbols, Abingdon, Routledge, 2012.

Jones, P. (2014), "Accommodating Religion and Shifting Burdens", Criminal Law and Philosophy, first published online, 24 July 2014, DOI 10.1007/s11572-014-9328-z., available at: http://link.springer.com/article/10.1007/s11572-014-9328-z (accessed 25 March 2015).

Kaminer, D. (2000), "When Religious Expression Creates a Hostile Work Environment: The Challenge of Balancing Competing Fundamental Rights", New York University Journal of Legislation and Public Policy, Vol. 4 No. 1, pp. 81-142.

Kandola, R. and Fullerton, J. (1998), Diversity in Action: Managing the Mosaic, London, Chartered Institute of Personnel and Development.

Kirton, G. and Greene, A. (2010), The Dynamics of Managing Diversity, Abingdon, Routledge.

Leader, S. (2007), "Freedom and Futures: Personal Priorities, Institutional Demands and Freedom of Religion", Modern Law Review, Vol. 70 No. 5, pp. 713-730.

Leigh, I. and Hambler, A. (2014), "Religious Symbols, Conscience and the Rights of Others", Oxford Journal of Law and Religion, Vol. 3 No. 1, pp. 2-24.

Leigh, I. and Masterman, R. (2008), Making Rights Real - The Human Rights Act in its First Decade, Oxford, Hart Publishing.

Lewis, R. (2013), "Hijab on the Shop Floor: Muslims in Fashion Retail in Britain," in Tarlow, E. and Moores, A. (Eds), Islamic Fashion and Anti-Fashion: New Perspectives from Europe and North America, London: Bloomsbury Academic, pp 181-200.

Litwak, E. (2005), "Conscientious Objection in Public Service Ethics: A Proposed Procedure for Europe", European Journal of Law, Vol. 7 No.1/2, pp. $79-87$.

Mantouvalou, V. (2008), "Human Rights and Unfair Dismissal: Private Acts in Public Spaces", Modern Law Review, Vol. 71 No. 6, pp. 912-939.

McCrudden, C. (2008), "Human Dignity and Judicial Interpretation of Human Rights", European Journal of International Law, Vol. 19 No. 4, pp. 655-724.

Mitchell, M., Beninger, K., Donald, A. and Howard, E. (2015), Religion or belief in the workplace and service delivery: Findings from a call for evidence, London, Equalities and Human Rights Commission.

Muslim Council of Britain (2005), Muslims in the Workplace: A Good Practice Guide for Employers and Employees, London, Muslim Council of Britain/Department of Trade and Industry. 
Osman-Gani, A., Hashim, J. and Ismail, Y. (2013), "Establishing linkages between religiosity and spirituality on employee performance", Employee Relations, Vol. 35 No. 4, pp. 360-376.

Parkinson, P. (2011), "Accommodating religious beliefs in a secular age: The issue of conscientious objection in the workplace", University of New South Wales Law Journal, Vol. 34 No. 1, pp. 281299.

Pava, M. (1998), "Religious Business Ethics and Political Liberalism: An Integrative Approach", Journal of Business Ethics, Vol. 17 No. 15, pp. 1633-1652.

Rawls, J. (1993), Political Liberalism, New York, Columbia University Press.

Rawls, J. (1997), "The Idea of Public Reason Revisited", University of Chicago Law Review, Vol. 64 No. 3, pp. 765-808.

Stahnke, T. (1999), "Proselytism and the Freedom to Change Religion in International Human Rights Law" Brigham Young University Law Review, Vol. 1, pp. 252-353.

Hunt, R. (2009), Religion and Sexual Orientation: How to manage relations in the workplace, London, Stonewall.

Tayeb, M. (1997), "Islamic revival in Asia and human resource management", Employee Relations, Vol. 19 No.4, pp. 352-364.

Vickers, L. (2010), "Religious Discrimination in the Workplace: An Emerging Hierarchy?", Ecclesiastical Law Journal, Vol. 12 No. 3, pp. 280-303.

Wilson, R. (2010), "Insubstantial Burdens: The Case for Government Employee Exemptions to SameSex Marriage Laws", Northwestern Journal of Law and Social Policy, Vol.5 No. 2, pp 318-368.

Wuthnow, R. (1998), God and mammon in America, New York, Simon and Schuster.

\section{List of Cases}

Amachree v Wandsworth Borough Council (2009) ET Case No. 2328606/2009

Azmi v Kirklees Metropolitan Borough Council (2007) EAT 0009/07

Chaplin v Royal Devon and Exeter NHS Foundation Trust (2010) ET Case No. 1702886/09

Chondol v Liverpool City Council (2009) EAT/0298/08

Eweida and Ors v United Kingdom Appl Nos. 48420/10, 59842/10, 51671/10 and 36516/10 (15 January 2013)

Kalac v Turkey (1997) 27 EHRR 552

Kokkinakis v Greece (1993) 17 EHRR 397

Ladele v Islington Borough Council EWCA Civ. 1357 (CA) [2009]; IRLR 211 [2010] 
Mba $v$ London Borough of Merton [2013] EWCA Civ 1562; [2013] WLR (D) 474 (CA)

Smith v Trafford Housing Trust [2012] EWHC 3221 (Ch) 